DOI: https://doi.org/10.24144/2409-6857.2019.2(54).104-109

УДК 657.471

Городиський М.П., Поліщук І.Р., Семйон В.С.

\title{
ПОРЯДОК РОЗПОДІЛУ ВИТРАТ НА ЗДІЙСНЕННЯ МАРКЕТИНГУ ЯК БІЗНЕС-ПРОЦЕСУ: ОБЛІКОВО-АНАЛІТИЧНИЙ АСПЕКТ
}

\begin{abstract}
Запропоновано маркетинг розглядати як основний бізнес-прочес підприємства, спрямований на створення попиту $і$ пропозиції товарів, формування оптимальних цін на товари для досягнення максимального споживання та довгострокового прибутку відповідно до стратегії розвитку підприємства. Вважаємо за дочільне застосовувати наступну класифікацію маркетингових витрат для цілей бухгалтерського обліку та економічного аналізу: залежно від обсягів реалізації; за відношенням до звітного періоду; за елементами витрат; за доцільністю; за маркетинговою стратегією розвитку підприємства. Розроблено методичний підхід до облікового відображення розподілу маркетингових витрат між звітними періодами, який дозволить відображати в бухгалтерському обліку не потениійний, а фактичний фінансовий результат від операційної діяльності, адже всі маркетингові витрати даного звітного періоду будуть розподілені між реалізованими товарами $і$ товарами на складі. Розподіл маркетингових витрат звітного періоду між реалізованою і нереалізованою продукцією стимулюватиме до виконання планів щуодо реалізації продукції і сприятиме ефективності роботи в иүілому підприємства.
\end{abstract}

Ключові слова: бізнес-прочес, маркетинг, маркетингові витрати, бухгалтерський облік, економічний аналіз, розподіл маркетингових витрат

Постановка проблеми. Для досягнення очікуваного рівня рентабельності операційної діяльності слід володіти повною і достовірною інформацією про структуру доходів від реалізації продукції (товарів, робіт, послуг) та операційних витрат. Витрати на збут як узагальнюючий показник фінансової звітності не містить аналітичної інформації про розмір витрат, безпосередньо пов'язаних зі збутом продукції, а також витрат, пов'язаних 3 уточненням маркетингової товарної та цінової політики щодо наявного та оновленого асортименту. Водночас діючі методичні підходи до облікового відображення витрат на збут не дозволяють управляти їх розміром залежно від обсягів реалізації звітного періоду, що призводить до відображення недостовірного фінансового результату від операційної діяльності у фінансовій звітності. Тому потребують уточнення класифікація витрат, пов'язаних з маркетинговою діяльністю, для цілей бухгалтерського обліку i економічного аналізу, а також удосконалення

() Городиський М.П., к.е.н., доц., доцент кафедри обліку і аудиту, Державний університет «Житомирська політехніка», E-mail: m.p.gorodysky@ztu.edu.ua

Поліщук I.P., к.е.н., доц., доцент кафедри обліку i аудиту Державний університет «Житомирська політехніка», E-mail: polishuk.irina.r@gmail.com Семйон В.С., к.е.н., доц., доцент кафедри обліку i аудити, Закарпатський угорський інститут імені Ференца Ракоці II, +38506648046, E-mail: semyonviktoria@gmail.com методики обліку маркетингових витрат та визначення фінансових результатів залежно від фактичних обсягів реалізації продукції.

Статистичні дані Державної служби статистики України про рентабельність операційної та всієї діяльності великих та середніх підприємств за видами економічної діяльності за січень-березень 2019 року [9] України свідчать про наявність найвищих показників ефективності операційної діяльності за такими видами операційної діяльності, як: операції 3 нерухомим майном - $39,8 \%$, інформація та телекомунікації - $24,3 \%$, оптова та роздрібна торгівля; ремонт автотранспортних засобів і мотоциклів - $24 \%$, а промисловість тільки $7 \%$. Тому детального дослідження потребують питання організації бухгалтерського обліку маркетингових витрат для одержання очікуваних обсягів реалізації продукції (товарів, робіт, послуг), фінансових результатів операційної діяльності та рентабельності операційної діяльності.

Аналіз останніх досліджень та публікацій. Питання сутності маркетингу як бізнес-процесу, розмежування маркетингових і збутових витрат, класифікації та аналітичного обліку маркетингових витрат та методичних підходів до аналізу маркетингових витрат характеризуються значною актуальністю, про що свідчать дослідження таких авторів, як: Гавришко Н.В. [2], Гудзенко Н.М. [3], Дерій В.А. [4], Колєнчук Г. [6], Шиманська А. [10]. Однак незважаючи на значні напрацювання вищезазначених авторів, залишаються не до кінця розкритими питання 
класифікації маркетингових витрат, порядку розподілу маркетингових витрат між звітними періодами для визначення об'єктивного фінансового результату.

Формулювання цілей статті Мета дослідження - уточнити сутність маркетингу як бізнес-процесу, удосконалити класифікацію маркетингових витрат, розробити методичний підхід до облікового відображення розподілу маркетингових витрат між звітними періодами.

Опис основного матеріалу дослідження. Маркетинг - основний бізнес-процес підприємства, спрямований на створення попиту і пропозиції товарів, формування оптимальних цін на товари для досягнення максимального споживання та довгострокового прибутку відповідно до стратегії розвитку підприємства.

Гудзенко Н.M. вважає, що збут - це завершальна стадія кругообороту капіталу; підсистема господарської діяльності, що включає процес переміщення продукції від виробника до споживача (реалізацію), спрямований на задоволення потреб останнього; управління рухом товарів 3 визначенням фінансового результату, який формується при створенні нової вартості в процесі виробництва. Організація процесу збуту $\epsilon$ складовою оперативногосподарської діяльності підприємства, на підвищення ефективності якої спрямовуються маркетингові зусилля. Збут більше стосується поточної діяльності, а маркетинг націлений на перспективу [3, С. 8].

Маркетингова політика підприємства - це механізм, що регулює просування конкурентоспроможного товару на ринку. Основними завданнями маркетингової політики $€: \quad 1)$ просування якісної та конкурентоспроможної продукції; 2) забезпечення задоволення споживачів; 3) максимізація прибутку; 4) оптимізація витрат на збут (основні витрати, пов'язані зі збутом продукції; допоміжні витрати, пов'язані 3 уточненням маркетингової товарної та цінової політики щодо наявного асортименту; витрати на розвиток маркетингової товарної та цінової політики щодо оновлення асортименту) залежно від маркетингової стратегії підприємства [7, С. 193]. Розглянемо детальніше сутність та види маркетингових витрат.

Гавришко Н.В. вважає, що маркетингові витрати - це витрати матеріальних, трудових, фінансових ресурсів підприємства, спрямовані на реалізацію обраної маркетингової тактики й стратегії, які включають: 1) проведення маркетингових досліджень; 2) планування асортиментної політики та здійснення інноваційної діяльності; 3) формування попиту і стимулювання $\quad$ збуту; 4 у управління маркетинговою діяльністю [2].

Відповідно до п. 19 П(С)БО 16 «Витрати» витрати на збут включають такі витрати, пов'язані 3 реалізацією (збутом) продукції (товарів, робіт, послуг): витрати пакувальних матеріалів для затарювання готової продукції на складах готової продукції; витрати на ремонт тари; оплата праці та комісійні винагороди продавцям, торговим агентам та працівникам підрозділів, що забезпечують збут; витрати на рекламу та дослідження ринку (маркетинг); витрати на передпродажну підготовку товарів; витрати на відрядження працівників, зайнятих збутом; витрати на утримання основних засобів, інших матеріальних необоротних активів, пов'язаних зі збутом продукції, товарів, робіт, послуг (операційна оренда, страхування, амортизація, ремонт, опалення, освітлення, охорона); витрати на транспортування, перевалку i страхування готової продукції (товарів), транспортноекспедиційні та інші послуги, пов'язані 3 транспортуванням продукції (товарів) відповідно до умов договору (базису) поставки; витрати на гарантійний ремонт і гарантійне обслуговування; витрати на страхування призначеної для подальшої реалізації готової продукції (товарів), що зберігається на складі підприємства; витрати на транспортування готової продукції (товарів) між складами підрозділів (філій, представництв) підприємства; інші витрати, пов'язані зі збутом продукції, товарів, робіт, послуг [8].

Гудзенко Н.М наголошує, що відповідно до чинного законодавства витрати на збут звітного періоду не включаються до собівартості реалізованої продукції, а списуються на фінансові результати і мають приховану форму. На основі узагальнення результатів дослідження 3 даної проблеми встановлено відсутність чіткої класифікації невиробничих витрат, до яких відносять витрати збутової діяльності. Науково обгрунтована класифікація витрат $є$ основою раціональної організації побудови обліку та сприяє ефективному здійсненню контролю i прийняттю управлінських рішень [3, С. 10]. Тому дослідження потребують підходи до класифікації маркетингових (збутових) витрат, запропоновані різними авторами.

Колєнчук $Г$. запропоновано наступну класифікацію маркетингових витрат, зокрема: 1) за елементами маркетинг-мікс «7Р» (продукт, ціна, просування, доведення продукту до споживача, персонал, процес, планування); 2) залежно від обсягу виробництва (змінні, 
постійні); 3) за способом зарахування до собівартості (прямі, непрямі) [6, С. 102].

Поділ маркетингових витрат за відношенням до конкретного виду продукції на прямі і непрямі доцільно здійснювати тільки для управлінської звітності, адже витрати на збут загальною сумою списуються на фінансові результати і не підлягають розподілу під час визначення кінцевого фінансового результату.

Далі розглянемо структуру витрат на збут, розроблену А. Шиманською: основні витрати на збут (витрати на управління збутом); додаткові витрати на збут (витрати на складування продукції, витрати на затарювання та упаковку продукції, витрати на транспортування); витрати на маркетинг (витрати на організацію та проведення маркетингових досліджень, витрати на розроблення та впровадження нового чи модифікованого продукту, витрати на формування попиту та стимулювання збуту, інші витрати на маркетинг) [10, С. 27].

Розглянувши підходи різних авторів до класифікації маркетингових витрат та вимоги П(С)БО 16 «Витрати» до структури витрат на збут запропоновано наступну класифікацію маркетингових витрат для цілей бухгалтерського обліку та економічного аналізу:

1) залежно від обсягів реалізації (змінні; постійні);

2) за відношенням до звітного періоду (витрати майбутніх періодів, витрати звітного періоду);

3) за елементами витрат (матеріальні витрати, витрати на оплату праці, $\mathrm{CCB}$, амортизація, інші витрати);

4) $3 \mathrm{a}$

доцільністю

(продуктивні, непродуктивні). Продуктивні витрати - основні витрати, пов'язані зі збутом продукції та уточненням маркетингової політики. Непродуктивні витрати - додаткові витрати, що виникають у результаті певних недоліків організації маркетингу на підприємстві;

5) за маркетинговою стратегією розвитку підприємства (основні витрати, пов'язані зі збутом продукції; допоміжні витрати, пов'язані $з$ уточненням маркетингової товарної та цінової політики щодо наявного асортименту; витрати на розвиток маркетингової товарної та цінової політики щодо оновлення асортименту.

На необхідності проведення аналізу непродуктивних витрат на збут наголошує B.А. Дерій, який стверджує, що витрати на збут можна, насамперед, аналізувати 3 позиції оперативного, тактичного (поточного) i стратегічного аналізу. В процесі оперативного аналізу аналізують витрати на збут за короткі проміжки часу (зміна, день, доба, п'ятиденка, тиждень, декада, половина місяця), що дає змогу миттєво виявляти непродуктивні витрати та ухвалювати за кожним 3 таких випадків оперативне управлінське рішення. Під час тактичного (поточного) аналізу здійснюється аналіз витрат на збут за середні проміжки часу (звітний місяць, квартал, рік), що дає змогу встановлювати суми непродуктивних витрат за довші періоди та ухвалювати тактичні управлінські рішення. В процесі стратегічного аналізу витрати на збут проектуються на відповідну перспективу (5-10 років) і ухвалюються стратегічні управлінські рішення [4, C. 23].

Розглянемо детальніше поділ маркетингових витрат за відношенням до звітного періоду на витрати майбутніх періодів і звітного періоду. Про важливість врахування витрат на збут залежно від обсягів реалізованої продукції наголошував ще Ж.Б. Дюмарше.

Він наполягав на необхідності одночасного розгляду рахунку товарів як 3 точки зору придбання (собівартість), так і 3 точки зору продажу (роздрібна ціна), причому остання відображає лише потенційний прибуток. Досить цікавими $\epsilon$ зауваження Ж.Б. Дюмарше щодо обліку торговельних витрат. Саме йому належить міркування про те, що необхідно всі витрати даного періоду розподіляти між реалізованими товарами і товарами на складі. На основі цього вчений робить висновок, що рахунок витрат обігу насправді є матеріальним рахунком [1, С. 52].

Відповідно до Інструкції про застосування Плану рахунків бухгалтерського обліку активів, капіталу, зобов'язань і господарських операцій підприємств і організацій рахунок 39 «Витрати майбутніх періодів» призначено для узагальнення інформації щодо здійснених витрат у звітному періоді, які підлягають віднесенню на витрати в майбутніх звітних періодах. За дебетом рахунку 39 «Витрати майбутніх періодів» відображається накопичення витрат майбутніх періодів, за кредитом - їх списання (розподіл) та включення до складу витрат звітного періоду. Аналітичний облік витрат майбутніх періодів ведеться за їх видами. Рахунок 39 «Витрати майбутніх періодів» кореспондує за дебетом 3 кредитом рахунків: 20 «Виробничі запаси», 37 «Розрахунки 3 різними дебіторами», 65 «Розрахунки за страхуванням», 66 «Розрахунки за виплатами працівникам», 68 «Розрахунки за іншими операціями». Рахунок 39 «Витрати майбутніх періодів» кореспондує за кредитом 3 дебетом рахунку 93 «Витрати на збут». На рахунку 93 «Витрати на збут» ведеться облік витрат, 
пов'язаних із збутом (реалізацією, продажем) продукції, товарів, робіт і послуг. За дебетом рахунку відображається сума визнаних витрат на збут, за кредитом - списання на рахунок 79 «Фінансові результати» [5].

Запропоновано розподіл маркетингових витрат звітного періоду здійснювати між реалізованою і нереалізованою продукцією. В разі виконання плану щодо реалізації продукції слід відображати суми понесених маркетингових витрат в складі рахунку 93 «Витрати на збут». У разі невиконання плану щодо реалізації продукції слід відображати суми маркетингових витрат в складі рахунку 39 «Витрати майбутніх періодів» в частині нереалізованої продукції та в складі рахунку 93 «Витрати на збут» в частині реалізованої продукції. Витрати, пов'язані 3 маркетинговою діяльністю, слід розподіляти між звітними періодами залежно від бази розподілу, затвердженої Положенням про облікову політику. Пропонуємо за базу розподілу використовувати обсяги реалізації продукції (товарів, робіт, послуг) в натуральному або вартісному вираженні.

Запропонований методичний підхід до облікового відображення розподілу маркетингових витрат між звітними періодами наведено на рис. 1.

Початок

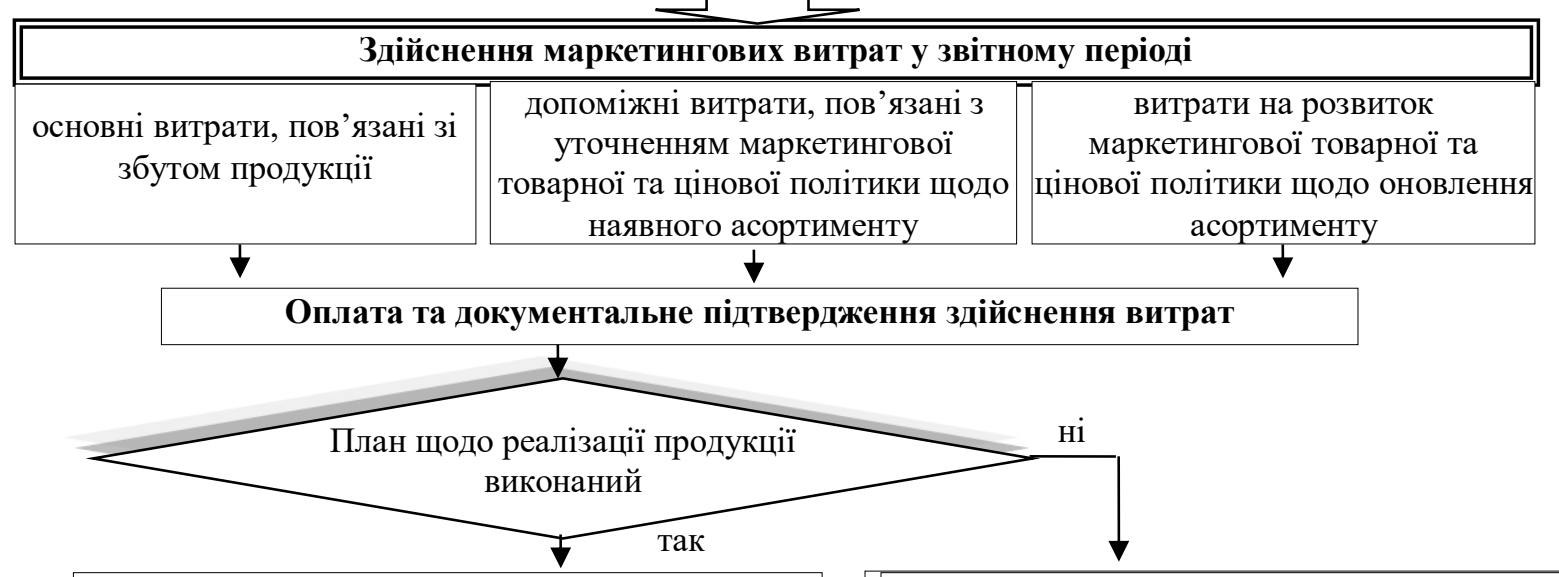

Відображення суми понесених маркетингових витрат в складі рахунку 93 «Витрати на збут» (Д 93 К 20, 66, 65, 13, 68)

Розподіл маркетингових витрат за обраною базою в Положенні про облікову політику

Обсяг реалізації в Обсяг реалізації в натуральному вираженні вартісному вираженні
Відображення суми маркетингових витрат в складі рахунку 93 «Витрати на збут» в частині реалізованої продукції (Д 93 К 20, 66, 65, 13, 68)

Документальне оформлення розподілу маркетингових витрат періодів» в частині нереалізованої продукції (Д 39 К 20, 66, 65, 13, 68)
Відображення суми маркетингових витрат в складі рахунку 39 «Витрати майбутніх

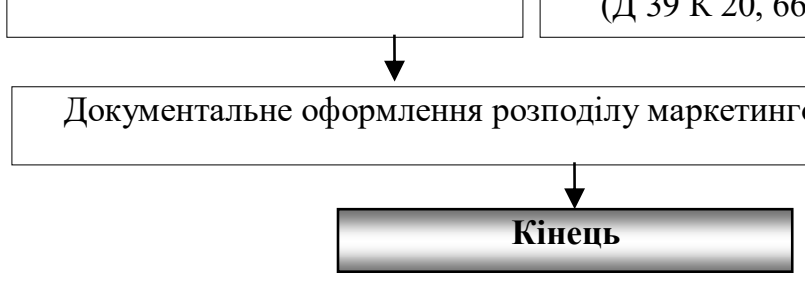

\section{Рис. 1. Методичний підхід до облікового відображення розподілу маркетингових витрат між звітними періодами}

Розроблений методичний підхід до облікового відображення розподілу маркетингових витрат між звітними періодами дозволить відображати в бухгалтерському обліку не потенційний, a фактичний фінансовий результат від операційної діяльності, адже всі маркетингові витрати даного звітного періоду будуть розподілені між реалізованими товарами і товарами на складі. 
Розподіл маркетингових витрат звітного періоду між реалізованою i нереалізованою продукцією стимулюватиме до виконання планів щодо реалізації продукції і сприятиме ефективності роботи в цілому підприємства.

Висновки та перспективи подальших досліджень. В ході дослідження обліковоаналітичного забезпечення порядку розподілу витрат на здійснення маркетингу як бізнес-процесу можна зробити наступні висновки:

1. Маркетинг - основний бізнес-процес підприємства, спрямований на створення попиту і пропозиції товарів, формування оптимальних цін на товари для досягнення максимального споживання та довгострокового прибутку відповідно до стратегії розвитку підприємства.

2. Розроблено класифікацію маркетингових витрат для цілей бухгалтерського обліку та економічного аналізу за такими ознаками: залежно від обсягів реалізації, за відношенням до звітного періоду, за елементами витрат, за доцільністю, за маркетинговою стратегією розвитку підприємства.

3. Запропоновано методичний підхід до облікового відображення розподілу маркетингових витрат між звітними періодами, в основу якого покладено виконання плану щодо реалізації продукції. У разі невиконання плану щодо реалізації продукції слід відображати суми маркетингових витрат в складі рахунку 39 «Витрати майбутніх періодів» в частині нереалізованої продукції та в складі рахунку 93 «Витрати на збут» в частині реалізованої продукції. Дані зміни дозволять відображати повну і достовірну інформацію про фінансовий результат від операційної діяльності в фінансовій звітності.

Перспективами подальших досліджень $\epsilon$ розробка методики аналізу ефективності маркетингу як бізнес-процесу.

\section{ПЕРЕЛІК ВИКОРИСТАНИХ ДЖЕРЕЛ}

1. Бутинець Ф.Ф. Історія бухгалтерського обліку: в 2 ч.: навч. посібник / Ф.Ф. Бутинець. - 2-е вид., доп. і перероб. - Ч. ІІ. - Житомир : ПП «Рута», 2001. - 512 с.

2. Гавришко Н.В. Облік і аналіз маркетингової та збутової діяльності: управлінський аспект (на прикладі підприємств хіміко-фармацевтичної промисловості України: Автореф. дис... канд. екон. наук: 08.06.04 / Н.В. Гавришко; Терноп. акад. нар. госп-ва. - Тернопіль, 2001. - 19 с.

3. Гудзенко Н.М. Облік і контроль збуту в операційній діяльності сільськогосподарських підприємств: Автореф. дис... канд. екон. наук: 08.06.04 / Н.М. Гудзенко ; Нац. аграр. ун-Т. - К., 2006. $20 \mathrm{c}$.

4. Дерій В.А. Витрати на збут у системі обліку й аналізу невиробничих витрат / В.А. Дерій // Облік і фінанси. - 2013. - № 4. - С. 20-23.

5. Інструкція про застосування Плану рахунків бухгалтерського обліку активів, капіталу, зобов'язань і господарських операцій підприємств і організацій: за станом на 18.03.2014 [Електронний pecyрс]. - Режим доступу: http://zakon4.rada.gov.ua/laws/show/z0892-99.

6. Колєнчук Г. Маркетингові витрати туристичних підприємств: обліковий аспект / Г. Колєнчук // Вісник КНТЕУ. - 2015. - № 5. - С. 95-106.

7. Поліщук I.P. Статистичне дослідження стану маркетингової політики: обліковий вимір / I.P. Поліщук // Проблеми теорії та методології бухгалтерського обліку, контролю і аналізу. Сер.: Бухгалтерський облік, контроль і аналіз. - 2016. - Вип. 1. - С. 190-203.

8. Положення (стандарт) бухгалтерського обліку 16 «Витрати» № 318 від 31.12 .99 р., затверджено Міністерством фінансів України (зі змінами на 09.08.2013 р.): [Електронний ресурс]. - Режим доступу: http://zakon2.rada.gov.ua/laws/show/z0027-00.

9. Рентабельність операційної та всієї діяльності великих та середніх підприємств за видами економічної діяльності за січень-березень 2019 року [Електронний ресурс]. - Режим доступу: http://www.ukrstat.gov.ua.

10. Шиманська А. Класифікація витрат на збут промислового підприємства / А. Шиманська // Маркетинг в Україні. - 2014. - № 5. - С. 24-28.

\section{REFERENCES}

1. Istorija buhgalters'kogo obliku [History of accounting]. PP «Ruta», Zhytomyr [in Ukrainian].

2. Gavryshko, N.V. (2001). Oblik i analiz marketyngovoi' ta zbutovoi' dijal'nosti: upravlins'kyj aspekt (na prykladi pidpryjemstv himiko-farmacevtychnoi' promyslovosti Ukrai'ny [Accounting and analysis of marketing and marketing activities: managerial aspect (on the example of the enterprises of the chemical- 
pharmaceutical industry of Ukraine]. Extended abstract of candidate's thesis. Ternop. akad. nar. gosp-va, Ternopil' [in Ukrainian].

3. Gudzenko, N.M. (2006), Oblik i kontrol' zbutu v operacijnij dijal'nosti sil's'kogospodars'kyh pidpryjemstv [Accounting and control of sales in operating activities of agricultural enterprises]. Extended abstract of candidate's thesis. Nac. agrar. un-t., Kyiv [in Ukrainian].

4. Derij, V.A. (2013). Vytraty na zbut u systemi obliku j analizu nevyrobnychyh vytrat [Sales costs in the system of accounting and analysis of non-production costs]. Oblik i finansy - Accounting and Finance, 4, 2023 [in Ukrainian].

5. Instruktsiya pro zastosuvannya Planu rakhunkiv bukhhalters'koho obliku aktyviv, kapitalu, zobovyazan' i hospodars'kykh operatsiy pidpryyemstv i orhanizatsiy za stanom na 18.03.2014 [Instruction on application of the Plan of accounts of accounting of assets, capital, liabilities and business transactions of enterprises and organizations from March 18,.2014] (March 18,.2014). zakon4.rada.gov.ua. Retrieved from: http://zakon4.rada.gov.ua/laws/show/z0892-99 [in Ukrainian].

6. Koljenchuk, G. (2015). Marketyngovi vytraty turystychnyh pidpryjemstv: oblikovyj aspekt [Marketing expenditures of tourist enterprises: accounting aspect], Visnyk KNTEU - Bulletin of KNTEU, 5, 95-106 [in Ukrainian].

7. Polishhuk, I.R. (2016). Statystychne doslidzhennja stanu marketyngovoi' polityky: oblikovyj vymir [A statistical study of the state of marketing policy: an accounting dimension]. Problemy teorii' ta metodologii' buhgalters'kogo obliku, kontrolju i analizu. Ser.: Buhgalters'kyj oblik, kontrol' i analiz - Problems of theory and methodology of accounting, control and analysis. Ser.: accounting, control and analysis, 1, 190-203 [in Ukrainian].

8. Polozhennya (standart) bukhhalters'koho obliku 16 «Vytraty» № 318 vid 31.12.99 r. [Regulation (standard) of accounting 16 «Expenses» № 318 from December 31, 1999]. (December 31, 1999). zakon2.rada.gov.ua. Retrieved from: http://zakon2.rada.gov.ua/laws/show/z0027-00 [in Ukrainian].

9. Rentabel'nist' operatsiynoyi ta vsiyeyi diyal'nosti velykykh ta serednikh pidpryyemstv za vydamy ekonomichnoyi diyal'nosti za sichen'-berezen' 2019 roku [Profitability of operating and all activities of large and medium-sized enterprises by types of economic activity for January-March 2019]. (n.d.). www.ukrstat.gov.ua. Retrieved from: http://www.ukrstat.gov.ua [in Ukrainian].

10.Shymans'ka, A. (2014). Klasyfikacija vytrat na zbut promyslovogo pidpryjemstva [Classification of sales costs of industrial enterprise]. Marketyng v Ukrai'ni - Marketing in Ukraine, 5, 24-28 [in Ukrainian].

Отримано 30.08.2019 